\title{
Understanding employee responses to COVID-19: a behavioral corporate social responsibility perspective
}

\section{Noções básicas sobre as respostas dos funcionários ao COVID-19: uma perspectiva comportamental sobre responsabilidade social corporativa}

Herman Aguinis, Isabel Villamor and Kelly P. Gabriel

Department of Management, School of Business, The George Washington

University, Washington, District of Columbia, USA

\begin{abstract}
Purpose - The purpose of this study is to critically synthesize and integrate conceptual and empirical research on the behavioral perspective on corporate social responsibility (CSR) and explain why it is useful and necessary, especially in the wake of the COVID-19 pandemic. The authors explain why CSR can result in
\end{abstract}

(C) Herman Aguinis, Isabel Villamor and Kelly P. Gabriel. Published by Emerald Publishing Limited. This article is published under the Creative Commons Attribution (CC BY 4.0) licence. Anyone may reproduce, distribute, translate and create derivative works of this article (for both commercial and non-commercial purposes), subject to full attribution to the original publication and authors. The full terms of this licence may be seen at http://creativecommons.org/licences/by/4.0/legalcode

The authors would like to thank Management Research Editor José Ernesto Amorós and two anonymous reviewers for their highly constructive feedback that allowed them to improve the manuscript. A previous version of this article was presented as a keynote address at the annual meetings of the Behavioral Science and Policy Association, May 2020.

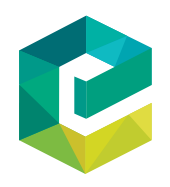

Management Research: Journal of the Iberoamerican Academy of Management pp. $421-438$

Emerald Publishing Limited DOI 10.1108/MRJLAM-06-2020-1053 
MRJIAM 18,4 both positive and negative outcomes and provide future research directions and recommendations for practice and policymaking.

Design/methodology/approach - This study focuses on critical literature review and synthesis.

Findings - CSR policies in response to COVID-19 are created by organizations but are implemented by individual employees. The way employees perceive and react to CSR actions are key determinants of CSR's implementation and success. CSR can be embedded within or peripheral to a firm's core functioning. While embedded CSR is linked to several positive outcomes if correctly implemented together with employees, peripheral CSR is linked to "the dark side" of CSR and can result in negative employee outcomes.

Practical and social implications - Using the backdrop of the COVID-19 pandemic, the authors detail types of CSR actions that governments and organizations can implement and their relative effectiveness; why "one size fits all" top-down CSR does not work; how firms can use human resource management practices to re-engage employees through finding meaning in work; and the "dark side" of CSR.

Originality/value - CSR research has focused mostly on why and when firms choose to engage in CSR. A behavioral perspective on CSR facilitates, through an employee-centric conceptual framework, a deeper understanding of when and why employee reactions lead to positive and unintended negative outcomes, especially during the COVID-19 pandemic.

Keywords Corporate social responsibility, Corporate social performance, COVID-19

Paper type Research paper

\section{Resumen}

Objetivo - Sintetizamos críticamente e integramos la investigación conceptual y empírica sobre la perspectiva conductual de la responsabilidad social corporativa (RSC) y explicamos por qué es útil y necesaria, especialmente a raíz de la pandemia del COVID-19. Explicamos por qué la RSC puede dar lugar a resultados tanto positivos como negativos y sugerimos propuestas para investigaciones futuras y recomendaciones para la práctica empresarial y la formulación de políticas.

Metodología - Revisión crítica y síntesis de literatura.

Resultados - Las políticas de RSC en respuesta a COVID-19 son creadas por organizaciones, pero implementadas por empleados. La forma en que los empleados perciben y reaccionan a las iniciativas de RSC es clave para la implementación y el éxito de la RSC. La RSC puede integrarse o ser periférica al funcionamiento central de una empresa. Si bien la RSC integrada está vinculada a varios resultados positivos si se implementa correctamente junto a los empleados, la RSC periférica está vinculada al "lado oscuro" de la RSC y puede generar resultados negativos para los empleados.

Originalidad/valor - La investigación de la RSC se ha centrado principalmente en cuándo y por qué las empresas eligen participar en la RSC. Una perspectiva conductual de la RSC facilita, a través de un marco conceptual centrado en los empleados, una comprensión más profunda de cuándo y por qué las reacciones de los empleados a la RSC conducen tanto a resultados positivos como a resultados negativos no deseados, especialmente durante la pandemia de COVID-19.

Implicaciones prácticas y sociales - Utilizando el telón de fondo de la pandemia de COVID-19, detallamos (1) los tipos de acciones de RSC que los gobiernos y las organizaciones pueden implementar y su relativa efectividad; (2) por qué la RSC de arriba hacia abajo y de "talla única” no funciona; (3) cómo las empresas pueden utilizar las prácticas de gestión de recursos humanos para volver a involucrar a los empleados mediante la búsqueda de significado en el trabajo; y (4) el "lado oscuro" de la RSC.

Palabras clave: COVID-19, Responsabilidad social corporativa

\section{Resumo}

Objetivo - Sintetizamos e integramos criticamente a pesquisa empírica e conceitual sobre a perspectiva comportamental da responsabilidade social corporativa (RSC) e explicamos por que ela é útil e necessária, especialmente após a pandemia do COVID-19. Explicamos por que a RSC pode levar a resultados positivos e negativos e sugerimos propostas para pesquisas futuras e recomendações para práticas de negócios e formulação de políticas.

Metodologia - Revisão crítica e síntese da literatura. 
Resultados - As políticas de RSC em resposta ao COVID-19 são criadas por organizações, mas implementadas pelos funcionários. O modo como os funcionários percebem e reagem às iniciativas de RSC é a chave para a implementação e o sucesso da RSC. A RSC pode ser integrada ou periférica à operação central de uma empresa. Enquanto a RSC integrada está vinculada a vários resultados positivos se implementado corretamente junto com os funcionários, a RSC periférica está vinculada ao "lado sombrio" da RSC e pode levar a resultados negativos para os funcionários.

Originalidade/valor - A pesquisa em RSC se concentrou principalmente em quando e por que as empresas optam por participar da RSC. Uma perspectiva comportamental da RSC fornece, através de uma estrutura conceitual centrada no funcionário, uma compreensão mais profunda de quando e por que as reações dos funcionários à RSC levam a resultados negativos positivos e indesejados,especialmente durante a pandemia de COVID-19.

Implicações práticas e sociais - Usando o pano de fundo da pandemia do COVID-19, detalhamos (1) os tipos de ações de RSC que governos e organizações podem implementar e sua relativa eficácia; (2) por que a RSC de cima para baixo e tamanho único não funciona; (3) como as empresas podem usar as práticas de gerenciamento de recursos humanos para reativar os funcionários buscando significado no trabalho; e (4) o "lado sombrio" da RSC.

Palavras-chave: COVID-19, Responsabilidade social corporativa.

In the wake of the COVID-19 pandemic, Amazon decided that embracing corporate social responsibility (CSR) was the right thing to do and therefore would focus on the triple bottom line of financial, social and environmental performance - not just profits. Specifically, Amazon drastically expanded online grocery delivery to provide an essential service for individuals affected by the pandemic (Amazon, 2020). However, with the increased need for fulfillment centers to run smoothly and at full capacity, the company began facing a lack of organizational commitment from workers as they protested unsafe conditions such as not having adequate protective equipment and working among many that have tested positiveor even died - from COVID-19 (Weise and Conger, 2020). A distinguished Engineer and VP at Amazon Web Services even resigned because of the company's handling of worker concerns amid the pandemic (Dolsak and Prakash, 2020). From the perspective of employees, this supposedly well-designed socially responsible initiative may have been well-intended, but it asked too much of employees and had detrimental effects.

The real story described in this opening paragraph is a good example of organizations implementing CSR policies to try to do the right thing during the COVID-19 pandemic. CSR has been defined as "any 'responsible' activity that allows a firm to achieve a sustainable competitive advantage, regardless of motive" (McWilliams and Siegel, 2011, p. 1480). Thus, the actions that Amazon took during the COVID-19 pandemic were part of their CSR initiatives. But the question is, given the evidence of an overall positive relationship between CSR and firm performance (Cantrell et al., 2015; Jayachandran et al., 2013; Margolis et al., 2009; Orlitzky et al., 2003), what went wrong? Why did a wellintended CSR initiative lead to unintended negative consequences (Pierce and Aguinis, 2015)? What can organizations do to produce win-win results as they focus on the three "Ps" simultaneously (i.e. profits, people and planet; Aguinis, 2011)? What do we know based on the vast literature on CSR that can help us answer these questions, and what are the questions that future research should address?

The goal of our article is to offer insights regarding these issues by embracing a fairly novel behavioral perspective on CSR. Most CSR research conducted to date has adopted a firm or institutional perspective (Aguinis and Glavas, 2012). In other words, CSR research has focused mostly on why and when firms choose to engage in CSR by, for example, examining a firm's mission and the values of its top management teams (i.e. firm approach), as well as laws, industry standards and stakeholder pressures (i.e. institutional approach). However, as we illustrated with the Amazon story, although CSR policies are created by organizations, they are implemented by individual employees. Moreover, the way employees perceive and react to CSR policies and

\section{Employee responses to \\ COVID-19}


MRJIAM 18,4

actions are key determinants of how they are implemented and their success or lack thereof (Aguinis and Glavas, 2019; Closon et al., 2015; Duarte et al., 2014; Duarte et al., 2010; El Akremi et al., 2018; Rupp and Mallory, 2015). A behavioral perspective on CSR goes beyond the more conventional firm and institutional perspectives and facilitates, through an employee-centric conceptual framework (Rupp and Mallory, 2015), a deeper understanding of when and why CSR can lead to different types of positive as well as unintended negative outcomes. We explain why a behavioral perspective is useful and necessary, especially in the wake of the COVID-19 pandemic, by relying on theories and empirical research from the fields of organizational behavior $(\mathrm{OB})$, human resource management (HRM) and others that focus on the individual and team levels of analysis (e.g. organizational psychology).

Our article is organized as follows. First, we explain the usefulness of a behavioral perspective on CSR, particularly in the backdrop of the COVID-19 pandemic. Second, we describe two types of CSR - embedded and peripheral (Aguinis and Glavas, 2013b) - and their impact on employees. Third, we discuss reasons why CSR, which is intended to lead to positive outcomes, can actually result in both positive as well as negative outcomes. Fourth, based on our critical review and synthesis of the literature, we offer seven suggestions for future research on behavioral CSR and COVID-19 and describe how Latin America is a particularly suitable context for pursuing two of them. Finally, based on the existing evidence, we describe how a behavioral perspective on CSR leads to useful recommendations for practice and policymaking in the wake of the pandemic.

\section{A behavioral corporate social responsibility perspective}

As we mentioned previously, research on CSR has traditionally focused on the firm and institutional levels of analysis and on assessing the relation between CSR and firm-level outcomes such as financial performance (Aguinis and Glavas, 2012; Duarte et al., 2010). In the past decade, however, conceptual and empirical research has expanded with a rise of a behavioral perspective on CSR (Closon et al., 2015; Duarte et al., 2014; Gond et al., 2017; Ng et al., 2019), what has often been labeled "micro-CSR" (Rupp and Mallory, 2015). This fairly new conceptual framework is person-centric and employee-centric in particular. Specifically, it focuses on how individuals experience and engage with CSR as they seek and find meaningfulness through work. Consequently, it also focuses on when and why employees experience CSR differently - resulting in differing positive outcomes for themselves, their organizations and external stakeholders (Aguinis and Glavas, 2019).

This shift toward a behavioral perspective on CSR started less than a decade ago. Aguinis and Glavas' (2012) multilevel review of the state of CSR research showed that, at that time, only $4 \%$ of the CSR-related articles in 17 highly regarded management and organization journals addressed the topic at the individual level of analysis. Also, in their review of CSR, Aguinis and Glavas (2012) ascertained that the CSR literature was largely macro-focused and neglected CSR's multilevel nature. Further, little CSR research had explored underlying mechanisms (i.e. mediating effects) through which CSR might result in differing outcomes for different individuals, organizations and stakeholders (Aguinis and Glavas, 2012).

Since Aguinis and Glavas's (2012) review - exemplified by Rupp and Mallory's (2015) review, only three years later - CSR research adopting a behavioral perspective has flourished. This research stream resulted in new insights into not only the positive and negative effects of CSR on employees but also in how to measure CSR. For example, El Akremi et al. (2018) developed and validated a multidimensional stakeholder-based measure of employees' CSR perceptions - the corporate stakeholder responsibility scale. By measuring CSR perceptions, we can now better understand why, how and when CSR perceptions are likely to lead to outcomes such as affective commitment, organizational identification and job satisfaction. 
Research on behavioral CSR has demonstrated empirical support for the positive effect of CSR on individual performance, organizational attitudes and organizational attraction (Rupp and Mallory, 2015 for a review). In terms of performance, CSR is positively related to organizational citizenship behaviors (Hansen et al., 2011; Rupp et al., 2013b), employee engagement (Caligiuri et al., 2013; Rupp et al., 2013a), effort (Jones, 2010), involvement and improved employee relations (Glavas and Piderit, 2009).

In terms of organizational attitudes, CSR is positively related to employee identification with the organization (Kim et al., 2010) and job satisfaction (De Roeck et al., 2014; Dhanesh, 2014). Hofman and Newman (2014) documented the importance of employee perceptions of CSR by finding that employees' perceptions of CSR practices toward internal (compared to external) stakeholders were positively related to organizational commitment.

Finally, in terms of organizational attraction, employees find organizations that engage in CSR to be more attractive (Backhaus et al., 2002). Positive organizational attraction outcomes of CSR include job pursuit intentions (Gully et al., 2013; Rupp et al., 2013b), professional development (Caligiuri et al., 2013) and retention (Jones, 2010). For example, Caligiuri et al. (2013) ascertained that employees' volunteer assignments were most valuable for engagement when employees were able to find meaning through their work, believe they contributed meaningfully, use their professional skills and develop skills useful for their typical work role.

However, there is also a "dark side of CSR." A growing literature on the behavioral perspective on CSR has examined the negative consequences that sometimes occur when choosing or implementing CSR initiatives. For example, Ormiston and Wong (2013) found that firms that engaged in CSR were subsequently more likely to engage in corporate social irresponsibility (CSiR), and CEOs who presented themselves as moral individuals were more likely to be associated with this positive relation between CSR and subsequent CSiR.

In the context of the COVID-19 pandemic, research focused on how firms can do good and do well is more critical than ever (Bapuji et al., 2020). However, conducting this type of useful and impactful research can be difficult when trying to make sense of the vast and diverse body of CSR work. A first step toward understanding the effects of CSR using a behavioral perspective is to distinguish the types of CSR policies that firms may implement in response to COVID-19 and their respective impact on employees. As a preview, the key findings on behavioral CSR, the differences between embedded versus peripheral CSR, their effects on employees and why CSR often results in mixed effects on employees in the context of COVID-19 are listed below:

Behavioral CSR: key findings

(1) Definition and conceptualization

- Focuses on how individuals experience and engage with CSR as they seek and find meaningfulness through work.

- Focuses on when and why employees experience CSR differently - resulting in differing positive outcomes for themselves, their organizations and external stakeholders.

- Research on behavioral CSR has demonstrated empirical support for the positive effect of CSR on individual performance, organizational attitudes and organizational attraction.

- There is also a "dark side of CSR:" a growing literature on the behavioral perspective of CSR has examined the negative consequences that sometimes occur when choosing or implementing CSR initiatives.

(2) Embedded versus peripheral CSR 
MRJIAM

18,4
- Embedded CSR relies on an organization's core competencies and integrates CSR within a firm's strategy, routines and operations.

- Peripheral CSR focuses on activities that are not integrated into an organization's strategy, routines and operations.

(3) Consequences of embedded versus peripheral CSR

- Embedded CSR is more likely to result in positive outcomes for employees when the CSR strategy is implemented taking them into consideration.

- When CSR is peripheral, employees do not engage with CSR every day, and they recognize that the CSR is not fully integrated within the organization. Employees involved in peripheral CSR might view it as symbolic or selfishly motivated by their firms.

(4) Reasons for differential consequences of embedded and peripheral CSR: the role of sense making

- Employees are actively thinking about and making sense of their organization and their roles as employees, individuals and members of society. This psychological process of sense making is a fruitful way to understand the underlying reasons why CSR results in these positive and negative effects.

- Sense making can be an underlying and unifying mechanism through which individuals engage with CSR to search for and find meaningfulness through work.

- CSR is a particularly salient conduit for individuals to seek and find meaningfulness through work because CSR affects many stakeholders and outcomes and thus expands the notion of work to go beyond a task or job.

\section{Embedded versus peripheral corporate social responsibility}

As Rupp and Mallory (2015) pointed out, CSR research faces a specificity dilemma. Several definitions and taxonomies of CSR have been proposed over time, most of them at the macro-level (Brammer et al., 2007; Matten and Moon, 2008; Waddock and Graves, 1997). Aguinis and Glavas (2013b) relied on the sustainability literature (Laszlo and Zhexembayeva, 2011) and suggested that CSR can be either embedded within or peripheral to the core functioning of a firm. This distinction between embedded CSR and peripheral CSR has become even more relevant in the recent pandemic. As firms quickly react to the new reality caused by COVID-19, they select the types of CSR initiatives to implement, often without considering the effects that these decisions may have on both their employees and their firms.

Embedded CSR relies on an organization's core competencies and integrates CSR within a firm's strategy, routines and operations and, therefore, affects all employees. In contrast, peripheral CSR focuses on activities that are not integrated into an organization's strategy, routines and operations (Aguinis and Glavas, 2013b). Although peripheral CSR can fulfill noble purposes and create shared value for organizations and society, it is not integrated into the daily practices and routines of the firm. Further, although organizations rarely fully embed CSR, most do implement some types of CSR, making the embedded-peripheral continuum useful (Aguinis and Glavas, 2013b).

This embedded-peripheral conceptualization of CSR is built into the psychological foundations of CSR (i.e. the underlying mechanisms and processes). Examples of these psychological foundations are the fulfillment of internal and external stakeholder needs (Aguinis and Glavas, 2013a, 2013b), values congruence (Edwards and Cable, 2009), meaningfulness in and at work (Rosso et al., 2010), perceptions of organizational justice (Rupp, 2011) and the ability for individuals to present more of their whole selves at work 
(Kahn, 1990). It is through these psychological foundations that embedded and peripheral CSR have differing effects on employees.

An example of a firm practicing embedded CSR is Intel (Aguinis and Glavas, 2013b), which integrates CSR into its strategy and daily practices. The "enrichment of lives of every person on earth" is part of Intel's core vision, and in its 2019-2020 CSR report Intel highlighted its 2030 strategic goals of "responsible, inclusive, and sustainable" practices enabled through their "technology, innovation, expertise, and the passion of [their] employees" (Intel, 2020, p. 7). Intel's strategy and vision are operationalized through all facets of the organization (Aguinis and Glavas, 2013b). For example, performance management systems incorporate CSR and influence employee compensation decisions. Also, "design for the environment" is a collaborative approach between departments to ensure that CSR is built into every aspect of engineering, manufacturing and R\&D (Aguinis and Glavas, 2013b). As a result of this embeddedness, employees across the organization become engaged and can find more meaningfulness in work, as there is a deeper purpose beyond short-term financial profit. In the context of COVID-19, Intel engaged in embedded CSR in committing $\$ 60 \mathrm{~m}$ dollars to accelerate access to the technology needed to combat the pandemic and at the same time committing $\$ 100 \mathrm{~m}$ to additional benefits, aid and compensation for its employees on the front lines (Intel, 2020). The company was able to leverage its pandemic leadership team created almost 20 years ago to ensure that its response was in line with its strategy, values and operations (Intel, 2020). With the resources and support from the company, employees have been engaging in creative CSR tactics, such as a group of Arizona employees who have been 3D printing face shields for first responders and vulnerable communities (We Are Intel, 2020).

Now, let us return to the case of Amazon we described at the beginning of our article. Expanding its online grocery delivery seemed to be consistent with Amazon's strategy given that it "strives to offer [its] customers the lowest possible prices, the best available selection, and the utmost convenience" (Amazon, 2020). However, the initiative was not integrated effectively into the company's routines and operations related to employee health and safety. Thus, this initiative was more peripheral than embedded.

Finally, we make an important clarification regarding the Intel and Amazon examples. These illustrations are not meant to portray these companies as being perfectly or not at all socially responsible. Rather, these cases are meant to illustrate the approach used toward CSR and thus the usefulness of the embedded versus peripheral CSR distinction to understand when and why CSR leads to positive outcomes.

\section{Consequences of embedded versus peripheral corporate social responsibility}

As Aguinis and Glavas (2019) explained, employees are affected positively when they perceive that CSR is embedded (Donia and Tetrault Sirsly, 2016). In contrast, when CSR is peripheral, employees do not engage with CSR every day, and they recognize that the CSR is not fully integrated within the organization. The reason for the stronger positive outcomes of embedded versus peripheral CSR is based on attribution theory. Specifically, employees involved in peripheral CSR might view it as symbolic or selfishly motivated by their firms (Aguinis and Glavas, 2019). Thus, it is not surprising that employees can have negative reactions to CSR when they are skeptical of the organization's claims (e.g. greenwashing) or when they view CSR as motivated by pure self-interest in profit (McShane and Cunningham, 2012).

Jones et al. (2016) delved into the psychological processes behind these negative reactions and asserted that the way CSR is implemented sends signals to prospective employees; employees can draw inferences about a company's working conditions, thus influencing their attraction to the job. As a specific illustration of this general finding, during the COVID-19 pandemic, Jeff Bezos (Amazon's CEO) donated $\$ 100 \mathrm{~m}$ to American food banks 
MRJIAM 18,4
(Liao, 2020), which will certainly have a positive impact on the food security of people in need. However, he faced backlash from employees and the media who viewed this donation as an intentional diversion from scrutiny over the lack of protection for warehouse and logistics workers during the pandemic (The Economist, 2020).

\section{Differential consequences of embedded and peripheral corporate social responsibility: the role} of sense making

What becomes apparent in our discussion of the positive and negative outcomes of embedded and peripheral CSR is that employees are actively thinking about and making sense of their organization and their roles as employees, individuals and members of society. This psychological process of sense making (Weick, 1995) is a fruitful way to understand the underlying reasons why CSR results in these positive or negative effects.

Employees are proactive and intentional agents who make sense and give meaning to their worlds - especially in new experiences such as the COVID-19 pandemic where people, organizations and society are encountering heightened levels of ambiguity and complexity. Aguinis and Glavas (2019) explored sense making as an underlying and unifying mechanism through which individuals engage with CSR to search for and find meaningfulness through work. CSR is a particularly salient conduit for individuals to seek and find meaningfulness through work because CSR affects many stakeholders and outcomes and thus expands the notion of work to go beyond a task or job. Consequently, this mechanism can explain when and why employees experience CSR in a particular manner and the resulting outcomes of those experiences (Aguinis and Glavas, 2019).

Through CSR and sense making, individuals can find meaning at work and in work (Aguinis and Glavas, 2013b). Through peripheral CSR, employees might find meaning at work, as they can see their employer engaging in CSR, but the employee's own job does not directly contribute to CSR. For example, seeing that Amazon has donated $\$ 5 \mathrm{~m}$ in Amazon devices globally to those in need (Amazon, 2020) may make an Amazon worker more proud of their employer even though their own job does not directly contribute to CSR (i.e. finding meaning at work). With embedded CSR, employees are more likely to find meaning at work and in work, as the CSR suffuses strategy and everyday routines and operations.

\section{Implications and opportunities for future research}

The organizational and societal context we are experiencing owing to COVID-19 brings a new need for research to improve our understanding of behavioral CSR. A behavioral perspective on CSR involves an expansion of conceptual and methodological frameworks. It also involves integrating varied fields (e.g. OB and HRM) and their theories that are impacted by CSR and sustainability issues (Aguinis and Glavas, 2013a). Because COVID-19 has impacted every country, business, industry and sector, there are numerous knowledge gaps and opportunities. In this section, we outline seven broad opportunities for future research. For the last two, we describe how conducting research specifically in Latin America would be particularly advantageous. As a preview, these future directions are listed below:

\section{Behavioral CSR and COVID-19: future research directions}

\section{(1) HRMpractices}

- Is it appropriate for job analysis, recruitment, selection, performance management, reward and training processes to consider CSR? If so, how should they be designed? If these classic HRM activities have already been designed to consider CSR, how should they change in response to COVID-19? 
- What specific HRM theories can be used to improve our understanding of the relation between CSR and COVID-19 (and potential future pandemics and natural disasters)?

(2) Bridging the micro-macro divide

- How are leadership characteristics related to firm-level CSR reactions to COVID-19?

- How do leaders' individual differences interact with firm-level factors (e.g. industry) in the selection of CSR initiatives?

(3) Measuring CSR's impact on stakeholders outside the firm

- What organizational systems and processes prevent the successful implementation of CSR initiatives related to COVID-19?

- What are sound ways to capture the dimensionality of embedded and peripheral CSR?

- What are the specific systems and processes that might lead to better outcomes for extra organizational stakeholders?

(4) Effects of CSR programs in reaction to COVID-19

- How do employees experience peripheral CSR (e.g. volunteering) while receiving compensation from their firm?

(5) Indicators of employee resistance to CSR

- What are the boundary conditions in how CSR structure (embedded versus peripheral) impacts employee outcomes?

- What individual differences (e.g. work-family orientation, political orientation) that create variation in the way employees make sense of, give meaning to, and react to CSR are heightened by the pandemic?

(6) Hybrid public-private collaborations

- What factors make these hybrid collaborations successful in responding to crises such as COVID-19?

- What are the consequences for both private and public enterprises that collaborate in these types of COVID-19 initiatives?

(7) Social inclusiveness, inequity and vulnerable populations

- What is the impact that CSR initiatives from firms in Latin America can have in mitigating inequality, and how can this translate into more meaningfulness in and at work?

First, research can explore how HRM practices are impacted by and, in turn, impact CSR responses to COVID-19 (Morgeson et al., 2013). There is currently an opportunity to continue integrating conceptual streams and expand the research on HRM practices and CSR (Stahl et al., 2020). Despite the explosive research in the past years linking CSR and microresearch (Gond et al., 2020; Gond et al., 2017; Rupp and Mallory, 2015), most of this research has addressed theories and domains in OB compared to HRM. Thus, there remains a need to understand how HRM practices can include CSR. Future research could address whether it is appropriate for job analysis, recruitment, selection, performance management, reward and training processes to consider CSR and, if so, how these classic HRM activities should be designed. Or, if these processes have already been designed to consider CSR, research can consider how they should change in response to COVID-19. Moreover, the specific HRM theories that can be used to improve our understanding of the relation between CSR and COVID-19 (and potential future pandemics and natural disasters) are also still unknown. 
MRJIAM 18,4

Second, bridging the much-lamented micro-macro divide (Aguinis et al., 2011; Aguinis and Glavas, 2012) and building on the multilevel nature of CSR (Andersson et al., 2013; Ren et al., 2017), future research can explore how leadership characteristics are related to firmlevel CSR reactions to COVID-19. For example, multilevel research can explore how leaders' individual differences might interact with firm-level factors, such as industry, in the selection of CSR initiatives (Aguinis and Molina-Azorín, 2015).

Third, related to the need to measure the impact of CSR on stakeholders outside the organization (e.g. community, environment and society; Barnett et al., 2020), understanding the organizational systems and processes that prevent the successful implementation of CSR initiatives related to COVID-19 could be a first step toward addressing the extra organizational impact of CSR. This research avenue provides the opportunity to develop ways to capture the dimensionality of embedded and peripheral CSR and the specific systems and processes that might lead to better outcomes for extra organizational stakeholders.

Fourth, future research might explore the effects of CSR programs in reaction to COVID-19 whereby employees engage in community service activities while receiving compensation from their firms. Organizations in the face of the pandemic are creating alternative ways to engage in CSR, with some attempting to deliver direct support to the community in the short term. Therefore, research that considers the way employees experience peripheral CSR, for example, by doing volunteering work but while receiving compensation, might lead to new insights on the nuances of how CSR structure (embedded versus peripheral) impacts employee outcomes.

Fifth, future research can explore the various indicators of employee resistance to CSR. Individual differences such as moral identity, communal values, work orientation and environmental values create variation in the way employees make sense of CSR (Aguinis and Glavas, 2019). The COVID-19 pandemic might be heightening some of these individual differences, such as work-family orientation or political orientation, that play a role in the way employees make sense of, give meaning to and react to CSR.

There are additional research opportunities related to the recent increase in research productivity in Latin America (Nicholls-Nixon et al., 2011; Ronda-Pupo, 2020; Ronda-Pupo and Katz, 2016) and Latin America's unique position to serve as a "natural laboratory" for building new theories and testing existing ones (Aguinis et al., 2020). Research on the behavioral perspective on CSR in Latin America would be uniquely valuable because it allows researchers to not rely on implicit assumptions of theories developed in the USA and other developed countries. Additionally, the region's relative homogeneity of institutional and economic conditions (CuervoCazurra, 2016), together with distinctive conditions in some Latin American countries, make this a fruitful context. Specifically, two broad areas suggested by Aguinis et al. (2020) can be particularly generative for expanding our knowledge of behavioral CSR generally and in the wake of the COVID-19 pandemic, as further described.

Sixth, Latin America is well-suited to address future research on behavioral CSR regarding hybrid public-private collaborations that often occur in this context. Latin American countries sometimes lack sufficient investment in infrastructure and social services, so private companies often engage in designing and executing public activities, crafting public-private partnerships that bridge execution with government regulation (Engel et al., 2014). Cabral et al. (2013) ascertained that private companies reduced costs without neglecting critical services, which can be especially important during a pandemic when critical services are in high demand. The COVID-19 pandemic increases the potential for these types of collaborations in industries as diverse as health or fashion (e.g. creation of masks and medical equipment). Overall, this creates a unique context to understand employee reactions to embedded CSR, the factors that make these hybrid collaborations 
successful in responding to crises such as COVID-19, and the consequences for both private and public enterprises that collaborate in these types of COVID-19 initiatives.

A final area for which Latin America also offers an advantageous context for future research on behavioral CSR is social inclusiveness, inequity and vulnerable populations (Aguinis et al., 2020). As with most crises and pandemics, those with less suffer the hardest consequences, and "the COVID-19 pandemic has once again forcefully pushed societal inequalities into public consciousness" (Bapuji et al., 2020, p. 2). Latin America offers a unique context to test how CSR initiatives can mitigate COVID-19's impact on the vulnerable conditions under which millions live (e.g. the case of Rio de Janeiro's favelas; Briso and Phillips, 2020) and how these CSR initiatives translate into more meaningfulness in and at work for the employees of these firms.

As shown in this section, COVID-19 has opened numerous future research areas. We described seven possible research directions. But, clearly, opportunities for future research abound and additional areas could be added to our list. For example, many organizations fail to adopt the practices that management research suggests are most effective, and this discrepancy between research and practice has been labeled the research-practice gap (Cascio and Aguinis, 2008; Rynes et al., 2018). Future research on behavioral CSR could include partnerships between researchers and practitioners, who together are likely to generate knowledge that is both rigorous and relevant. Second, there is a rather vast literature on organizational responses to crises and adversities (Bundy et al., 2017; Williams et al, 2017). Future research could try to understand whether a behavioral CSR perspective is also useful for understanding employee responses to other types of crises and extreme situations.

\section{Implications for organizational practices and policymaking}

The research we synthesized and integrated in the previous sections has multiple useful implications for practitioners and policymakers. As a preview, these implications are listed below:

Behavioral CSR and COVID-19: implications for organizational practices and policymaking

- When selecting a CSR strategy, leaders should keep in mind that embedded CSR (i.e. CSR that involves an organization's core competencies and integrates CSR within a firm's strategy, routines and operations) has been linked to positive outcomes for both the firm and employees when correctly implemented taking into account employees. Peripheral CSR (i.e. CSR that is not integrated with the firm's strategy, routines and operations but is based on initiatives such as donations or volunteering) results in mixed outcomes at best.

- "One size fits all” CSR does not always work. Employees involved in peripheral CSR might view it as symbolic or selfishly motivated by their firms and can have negative reactions to CSR when they are skeptical of the organization's claims (e.g. green washing) or when they view CSR as motivated by pure self-interest in profit. This provides an important caution to leaders seeking to implement CSR for image or public relations reasons. Employees quickly understand the type of CSR in which their organization is engaging.

- CSR initiatives can have negative effects on employees (i.e. the "dark side of CSR"). If a CSR initiative is peripheral and is also forced top-down on employees, it can backfire.

- HRM practices such as performance management and compensation can be helpful in making employees aware of CSR and show the firm's commitment to CSR. For example, employee performance evaluations and salary decisions can be based in 
MRJIAM 18,4 part on employees' contributions to a firm's CSR initiatives. In other words, employees can get "performance points" and bonuses for being active participants in CSR. Because CSR is linked to sense making, making employees aware of and accountable for the firm's CSR involvement can lead to employee re-engagement through finding more meaningfulness in work.

First, our discussion of different types of CSR is useful regarding actions that governments and organizations of all types and in all industries can implement and their anticipated effectiveness. Embedded CSR involves an organization's core competencies and integrates CSR within a firm's strategy, routines and operations, while peripheral CSR does not. Embedded CSR affects all employees as well as external stakeholders in multiple ways, including, among others, fulfilling internal and external stakeholder needs, enhancing consumer and employee pride and identification and providing a conduit to seek and find meaningfulness in and at work.

Second, we explained why "one size fits all" CSR does not always work, which accounts for the documented variance in outcomes of CSR ranging from positive to neutral and even to negative. This provides an important caution to organizations seeking to implement CSR for image or public relations reasons. Employees quickly understand whether their organization is engaged in embedded or peripheral CSR. While embedded CSR is related to several positive outcomes when correctly implemented with employees in mind, this is not always the case for peripheral CSR.

Third, we described negative effects of CSR, what we refer to as the "dark side of CSR," as not all CSR initiatives and strategies have a positive impact on employees. Consider a situation where CSR is not only peripheral but is also forced top-down on employees. Leaders could be pushing for employees to engage in CSR while performance management systems encourage a focus on short-term financial results. In such situations where CSR is peripheral, symbolic and pushed top-down on employees, CSR can backfire. Leaders in Latin America should pay special attention to this point as a top-down leadership style is more common in this region. Both quantitative (Howell et al., 2007) and qualitative (D'Iribarne, 2002; Lindsley and Braithwaite, 1996; Rodriguez and Rios, 2008) cross-cultural research has found that authority-based and collective values in Latin America result in a unique leadership style characteristic of Latin America compared to the USA or Europe (Castaño et al., 2015). Specifically, this is typically referred to as the autocratic model of leadership and, more recently, paternalism leadership (Davila and Elvira, 2012), which combines high authority with close personal relationships and emphasizes the relationship orientation of respecting power and authority (Martinez, 2005).

Finally, we elaborated on how organizations and government agencies can use HRM practices such as performance management (Aguinis, 2019) and compensation to make employees aware of CSR - which as a result, could increase employees' trust in their organization's commitment to CSR (as they are showing their commitment and not just talking about it). For example, employee performance evaluations and salary decisions can be based in part on employees' contributions to a firm's CSR initiatives. In other words, employees can get "performance points" and bonuses for being active participants in CSR. Because CSR is linked to sense making, making employees aware of and accountable for the firm's CSR involvement can lead to employee re-engagement by finding more meaningfulness in work.

\section{Mini case study: Amazon}

Given our previous summary of research findings and their implications for practice, let us now revisit the situation faced by Amazon as described in the opening vignette in our 
article. While Amazon's CSR initiative could have been an embedded CSR strategy because it involved one of the Amazon's core competencies (online delivery of goods) and was integrated within the firm's strategy, the firm seems to have failed to implement it in a way that involved employees. In other words, it likely was a "one size fits all" top-down CSR strategy that, as often happens, did not work as expected. Moreover, Bezos' donation, a peripheral CSR action, created further backlash (The Economist, 2020). Employees and the media quickly reacted against it as they considered it a hypocritical action to distract attention from the unsanitary conditions and high-risk situations that employees felt they were facing as a consequence of the CSR strategy to expand online grocery delivery. Amazon could have designed its expanded grocery delivery service with employee involvement and safety conditions in mind; used HRM practices such as performance management and compensation to make employees aware of CSR; and showed the firm's commitment to CSR (e.g. linking performance evaluations and salary decisions to employees' contributions to a firm's CSR initiatives). Had Amazon done that, employees would have been more likely to join the strategy and also become reenergized and find new meaningfulness through their work rather than resisting the CSR initiatives.

\section{Concluding remarks}

We described why a behavioral perspective on CSR is useful and necessary, especially in the context of the COVID-19 pandemic. Also, we described two types of CSR - embedded and peripheral - and their effects on employees, and we shed light on the reasons why CSR can result in both positive and negative outcomes for employees (refer to "Behavioral CSR: key findings"). Then, we offered suggestions for future research, such as how HRM practices are impacted by and, in turn, impact CSR responses to COVID-19 and pointed out the unique opportunity of research in Latin America to address these future research avenues (refer to "Behavioral CSR and COVID-19: future research directions"). Finally, based on the existing evidence, we offered recommendations on how a behavioral perspective on CSR is useful for practice and policymaking (refer to "Behavioral CSR and COVID-19: implications for organizational practices and policymaking"). Overall, a behavioral perspective on CSR offers novel theoretical insights on when and why CSR initiatives work as intended and when they do not, which is a critical information as organizations in all industries and of all types, as well as entire countries, implement actions and policies in response to COVID-19.

\section{References}

Aguinis, H. (2011), "Organizational responsibility: doing good and doing well", Zedeck, S. (Ed.), APA Handbook of Industrial and Organizational Psychology, Vol. 3: Maintaining, Expanding, and Contracting the Organization, American Psychological Association, Washington, DC, pp. 855-879.

Aguinis, H. (2019), Performance Management, 4th ed., Chicago Business Press, IL.

Aguinis, H., Boyd, B.K., Pierce, C.A. and Short, J.C. (2011), "Walking new avenues in management research methods and theories: bridging micro and macro domains", Journal of Management, Vol. 37 No. 2, pp. 395-403, doi: 10.1177/0149206310382456.

Aguinis, H. and Glavas, A. (2012), "What we know and don't know about corporate social responsibility: a review and research agenda", Journal of Management, Vol. 38 No. 4, pp. 932-968, doi: $10.1177 \% 2 \mathrm{~F} 0149206311436079$.

Aguinis, H. and Glavas, A. (2013a), "What corporate environmental sustainability can do for industrialorganizational psychology", Huffman, A. H. and Klein, S. R. (Eds), Green Organizations: Driving Change with I-O Psychology, Routledge, New York, NY, pp. 379-392. 
MRJIAM 18,4

Aguinis, H. and Glavas, A. (2013b), "Embedded versus peripheral corporate social responsibility: psychological foundations", Industrial and Organizational Psychology, Vol. 6 No. 4, pp. 314-332, doi: 10.1111/iops.12059.

Aguinis, H. and Glavas, A. (2019), "On corporate social responsibility, sensemaking, and the search for meaningfulness through work", Journal of Management, Vol. 45 No. 3, pp. 1057-1086, doi: $10.1177 \% 2 \mathrm{~F} 0149206317691575$.

Aguinis, H. and Molina-Azorín, J.F. (2015), "Using multilevel modeling and mixed methods to make theoretical progress in microfoundations for strategy research", Strategic Organization, Vol. 13 No. 4, pp. 353-364, doi: 10.1177/1476127015594622.

Aguinis, H., Villamor, I., Lazzarini, S.G., Vassolo, R.S., Amorós, J.E. and Allen, D.G. (2020), “Conducting management research in Latin America: why and what's in it for you?", Journal of Management, Vol. 46 No. 5, pp. 615-636, doi: $10.1177 \% 2 F 0149206320901581$.

Amazon (2020), "Amazon's COVID-19 blog: daily updates on how we're responding to the crisis", available at: https://blog.aboutamazon.com/company-news/amazons-actions-to-help-employeescommunities-and-customers-affected-by-covid-19

Andersson, L., Jackson, S.E. and Russell, S.V. (2013), "Greening organizational behavior: an introduction to the special issue", Journal of Organizational Behavior, Vol. 34 No. 2, pp. 151-155, doi: 10.1002/job.1854.

Backhaus, K.B., Stone, B.A. and Heiner, K. (2002), "Exploring the relationship between corporate social performance and employer attractiveness", Business and Society, Vol. 41 No. 3, pp. 292-318, doi: $10.1177 \%$ 2F0007650302041003003.

Bapuji, H., Patel, C., Ertug, G. and Allen, D.G. (2020), "Corona crisis and inequality: why management research needs a societal turn", Journal of Management, doi: 10.1177\%2F0149206320925881

Barnett, M.L., Henriques, I. and Husted, B.W. (2020), "Beyond good intentions: designing CSR initiatives for greater social impact", Journal of Management, Vol. 46 No. 6, pp. 937-964, doi: $10.1177 / 0149206319900539$.

Brammer, S., Millington, A. and Rayton, B. (2007), "The contribution of corporate social responsibility to organizational commitment", The International Journal of Human Resource Management, Vol. 18 No. 10, pp. 1701-1719, doi: 10.1080/09585190701570866.

Briso, C. B. and Phillips, T. (2020), "Rio's favelas count the cost as deadly spread of covid-19 hits city's poor", The Guardian, available at: www.theguardian.com/world/2020/apr/25/rio-favelas-coronavirus-brazil

Bundy, J., Pfarrer, M.D., Short, C.E. and Coombs, W.T. (2017), "Crises and crisis management: integration, interpretation, and research development", Journal of Management, Vol. 43 No. 6, pp. 1661-1692, doi: 10.1177/0149206316680030.

Cabral, S., Lazzarini, S.G. and Azevedo, P.F. (2013), "Private entrepreneurs in public services: a longitudinal study of outsourcing and statization in prisons", Strategic Entrepreneurship Journal, Vol. 7 No. 1, pp. 6-25, doi: 10.1002/sej.1149.

Caligiuri, P., Mencin, A. and Jiang, K. (2013), "Win-win-win: the influence of company-sponsored volunteerism programs on employees, NGOs, and business units", Personnel Psychology, Vol. 66 No. 4, pp. 825-860, doi: 10.1111/peps.12019.

Cantrell, J.E., Kyriazis, E. and Noble, G. (2015), "Developing CSR giving as a dynamic capability for salient stakeholder management”, Journal of Business Ethics, Vol. 130 No. 2, pp. 403-421, doi: 10.1007/s10551-014-2229-1.

Cascio, W.F. and Aguinis, H. (2008), "Research in industrial and organizational psychology from 1963 to 2007: changes, choices, and trends", Journal of Applied Psychology, Vol. 93 No. 5, pp. 1062-1081, doi: 10.1037/ 0021-9010.93.5.1062.

Castaño, N., de Luque, M.F.S., Wernsing, T., Ogliastri, E., Shemueli, R.G., Fuchs, R.M. and RoblesFlores, J.A. (2015), "El jefe: differences in expected leadership behaviors across Latin American countries", Journal of World Business, Vol. 50 No. 3, pp. 584-597, doi: 10.1016/j.jwb.2014.12.002. 
Closon, C., Leys, C. and Hellemans, C. (2015), "Perceptions of corporate social responsibility, organizational commitment and job satisfaction", Management Research: Journal of the Iberoamerican Academy of Management, Vol. 13 No. 1, pp. 31-54, doi: 10.1108/MRJIAM-09-20140565.

Cuervo-Cazurra, A. (2016), "Multilatinas as sources of new research insights: the learning and escape drivers of international expansion”, Journal of Business Research, Vol. 69 No. 6, pp. 1963-1972, doi: 10.1016/j.jbusres.2015.10.142.

D'Iribarne, P. (2002), "Motivating workers in emerging countries: universal tools and local adaptations", Journal of Organizational Behavior, Vol. 23 No. 3, pp. 1-14, doi: 10.1002/job.142.

Davila, A. and Elvira, M.M. (2012), "Humanistic leadership: lessons from Latin America", Journal of World Business, Vol. 47 No. 4, pp. 548-554, doi: 10.1016/j.jwb.2012.01.008.

De Roeck, K., Marique, G., Stinglhamber, F. and Swaen, V. (2014), "Understanding employees' responses to corporate social responsibility: mediating roles of overall justice and organizational identification", The International Journal of Human Resource Management, Vol. 25 No. 1, pp. 91-112, doi: 10.1080/09585192.2013.781528.

Dhanesh, G.S. (2014), "CSR as organization-employee relationship management strategy: a case study of socially responsible information technology companies in India", Management Communication Quarterly, Vol. 28 No. 1, pp. 130-149, doi: 10.1177\%2F0893318913517238

Dolsak, N. and Prakash, A. (2020), "Whistleblowers fired, VP resigns: Amazon's looming political problems", Forbes, available at: www.forbes.com/sites/prakashdolsak/2020/05/07/ whistleblowers-fired-vp-resigns-amazons-looming-political-problems/\#6ed560757f1d.

Donia, M.B. and Tetrault Sirsly, C.A. (2016), "Determinants and consequences of employee attributions of corporate social responsibility as substantive or symbolic", European Management Journal, Vol. 34 No. 3, pp. 232-242, doi: 10.1016/j.emj.2016.02.004.

Duarte, A.P., Gomes, D. and Neves, J. (2014), "Finding the jigsaw piece for our jigsaw puzzle with corporate social responsibility: the impact of CSR on prospective applicants' responses", Management Research: Journal of the Iberoamerican Academy of Management, Vol. 12 No. 3, pp. 240-258, doi: 10.1108/MRJIAM-11-2013-0532.

Duarte, A.P., Mouro, C. and das Neves, J.G. (2010), “Corporate social responsibility: mapping its social meaning", Management Research: Journal of the Iberoamerican Academy of Management, Vol. 8 No. 2, pp. 101-122, doi: 10.1108/1536-541011066461.

Edwards, J.R. and Cable, D.M. (2009), “The value of value congruence”, Journal of Applied Psychology, Vol. 94 No. 3, pp. 654-677, doi: 10.1037/a0014891.

El Akremi, A., Gond, J.P., Swaen, V., De Roeck, K. and Igalens, J. (2018), "How do employees perceive corporate responsibility? Development and validation of a multidimensional corporate stakeholder responsibility scale", Journal of Management, Vol. 44 No. 2, pp. 619-657, doi: 10.1177\%2F0149206315569311.

Engel, E., Fischer, R.D. and Galetovic, A. (2014), The Economics of Public-Private Partnerships: A Basic Guide, Cambridge University Press, Cambridge.

Glavas, A. and Piderit, S.K. (2009), "How does doing good matter", Journal of Corporate Citizenship, Vol. 2009 No. 36, pp. 51-70.

Gond, J.P., El Akremi, A., Swaen, V. and Babu, N. (2017), "The psychological microfoundations of corporate social responsibility: a person-centric systematic review", Journal of Organizational Behavior, Vol. 38 No. 2, pp. 225-246, doi: 10.1002/job.2170.

Gond, J.P. Mena, S. and Mosonyi, S. (2020), "The performativity of literature reviewing: constituting the corporate social responsibility literature through re-presentation and intervention", Organizational Research Methods, available at: https://openaccess.city. ac.uk/id/eprint/24251 
MRJIAM 18,4

Gully, S.M., Phillips, J.M., Castellano, W.G., Han, K. and Kim, A. (2013), “A mediated moderation model of recruiting socially and environmentally responsible job applicants", Personnel Psychology, Vol. 66 No. 4, pp. 935-973, doi: 10.1111/peps.12033.

Hansen, S.D., Dunford, B.B., Boss, A.D., Boss, R.W. and Angermeier, I. (2011), "Corporate social responsibility and the benefits of employee trust: a cross-disciplinary perspective", Journal of Business Ethics, Vol. 102 No. 1, pp. 29-45, doi: 10.1007/s10551-011-0903-0.

Hofman, P.S. and Newman, A. (2014), "The impact of perceived corporate social responsibility on organizational commitment and the moderating role of collectivism and masculinity: evidence from China", The International Journal of Human Resource Management, Vol. 25 No. 5, pp. 631-652, doi: 10.1080/ 09585192.2013.792861.

Howell, J.P., De la Cerda, J., Martinez, S.M., Prieto, L., Bautista, J.A., Ortiz, J. and Méndez, M.J. (2007), “Leadership and culture in Mexico", Journal of World Business, Vol. 42 No. 4, pp. 449-462, doi: 10.1016/j. jwb.2007.06.006.

Intel (2020), “2019-2020 Corporate responsibility at intel”, available at: http://csrreportbuilder.intel.com/ pdfbuilder/pdfs/CSR-2019-20-Full-Report.pdf

Jayachandran, S., Kalaignanam, K. and Eilert, M. (2013), "Product and environmental social performance: varying effect on firm performance", Strategic Management Journal, Vol. 34 No. 10, pp. 1255-1264, doi: 10.1002/smj.2054.

Jones, D.A. (2010), "Does serving the community also serve the company? using organizational identification and social exchange theories to understand employee responses to a volunteerism programme", Journal of Occupational and Organizational Psychology, Vol. 83 No. 4, pp. 857-878, doi: 10.1348/ 096317909X477495.

Jones, D.A., Willness, C.R. and Heller, K.W. (2016), "Illuminating the signals job seekers receive from an employer's community involvement and environmental sustainability practices: insights into why most job seekers are attracted, others are indifferent, and a few are repelled", Frontiers in Psychology, Vol. 7 No. Article 426, pp. 95-109, doi: 10.3389/fpsyg.2016.00426.

Kahn, W.A. (1990), "Psychological conditions of personal engagement and disengagement at work", Academy of Management Journal, Vol. 33 No. 4, pp. 692-724, doi: 10.5465/256287.

Kim, H.R., Lee, M., Lee, H.T. and Kim, N.M. (2010), "Corporate social responsibility and employee-company identification", Journal of Business Ethics, Vol. 95 No. 4, pp. 557-569, doi: 10.1007/s10551-010-0440-2.

Laszlo, C. and Zhexembayeva, N. (2011), Embedded Sustainability: The Next Big Competitive Advantage, Stanford University Press, Palo Alto, CA.

Liao, S. (2020), “Jeff bezos is donating $\$ 100$ million to American food banks", CNN business", available at: www.cnn.com/2020/04/03/tech/jeff-bezos-food-bank-donationcoronavirus/index.html

Lindsley, S.L. and Braithwaite, C.A. (1996), "You should 'wear a mask': facework norms in cultural and intercultural conflict in maquiladoras", International Journal of Intercultural Relations, Vol. 20 No. 2, pp. 199-225, doi: 10.1016/0147-1767(96)00002-8.

Margolis, J., Elfenbein, H., Walsh, J. (2009), "Does it pay to be good. . .and does it matter? A Metaanalysis of the relationship between corporate social and financial performance", SSRN Electronic Journal, doi: 10.2139/ssrn.1866371.

McShane, L. and Cunningham, P. (2012), "To thine own self be true? Employees' judgments of the authenticity of their organization's corporate social responsibility program”, Journal of Business Ethics, Vol. 108 No. 1, pp. 81-100, doi: 10.1007/s10551-011-1064-x.

McWilliams, A. and Siegel, D.S. (2011), "Creating and capturing value: strategic corporate social responsibility, resource-based theory, and sustainable competitive advantage”, Journal of Management, Vol. 37 No. 5, pp. 1480-1495, doi: 10.1177/0149206310385696. 
Martinez, P.G. (2005), "Paternalism as a positive form of leadership in the Latin American context: leader benevolence, decision-making control and human resource management practices", Elvira, M. and Davila, A. (Eds.), Managing Human Resources in Latin America: An Agenda for International Leaders, Routledge, Oxford, pp. 75-93.

Matten, D. and Moon, J. (2008), "Implicit" and "explicit" CSR: a conceptual framework for a comparative understanding of corporate social responsibility", Academy of Management Review, Vol. 33 No. 2, pp. 404-424, doi: 10.5465/amr.2008.31193458.

Morgeson, F.P., Aguinis, H., Waldman, D.A. and Siegel, D.S. (2013), "Extending corporate social responsibility research to the human resource management and organizational behavior domains: a look to the future", Personnel Psychology, Vol. 66 No. 4, pp. 805-824, doi: 10.1111/peps.12055.

Ng, T.W., Yam, K.C. and Aguinis, H. (2019), "Employee perceptions of corporate social responsibility: effects on pride, embeddedness, and turnover", Personnel Psychology, Vol. 72 No. 1, pp. 107-137, doi: 10.1111/peps.12294.

Nicholls-Nixon, C.L., Davila Castilla, J.A., Sanchez Garcia, J. and Rivera Pesquera, M. (2011), "Latin America management research: review, synthesis, and extension”, Journal of Management, Vol. 37 No. 4, pp. 1178-1227, doi: $10.1177 \% 2 F 0149206311403151$.

Orlitzky, M., Schmidt, F.L. and Rynes, S.L. (2003), "Corporate social and financial performance: a metaanalysis”, Organization Studies, Vol. 24 No. 3, pp. 403-441, doi: 10.1177\%2F0170840603024003910.

Ormiston, M.E. and Wong, E.M. (2013), "License to ill: the effects of corporate social responsibility and CEO moral identity on corporate social irresponsibility", Personnel Psychology, Vol. 66 No. 4, pp. 861-893, doi: 10.1111/peps.12029.

Pierce, J.R. and Aguinis, H. (2015), "Detrimental citizenship behaviour: a multilevel framework of antecedents and consequences", Management and Organization Review, Vol. 11 No. 1, pp. 69-99, doi: $10.1111 /$ more.12015.

Ren, S., Tang, G. and Jackson, S.E. (2017), "Green human resource management research in emergence: a review and future directions", Asia Pacific Journal of Management, Vol. 35 No. 3, pp. 769-803, doi: 10.1007/s10490-017-9532-1.

Rodriguez, D. and Rios, R. (2008), "Latent premises of labor contracts: Paternalism and productivity", International Journal of Manpower, Vol. 28 No. 5, pp. 354-368, doi: 10.1108/01437720710778367.

Ronda-Pupo, G.A. (2020), "The performance of Latin American research on economics and business", Scientometrics, Vol. 122 No. 1, pp. 573-590, doi: 10.1007/s11192-019-03300-y.

Ronda-Pupo, G.A. and Katz, J.S. (2016), “The power-law relationship between citation-based performance and collaboration in articles in management journals: a scale-independent approach", Journal of the Association for Information Science and Technology, Vol. 67 No. 10, pp. 2565-2572, doi: 10.1002/asi.23575.

Rosso, B.D., Dekas, K.H. and Wrzesniewski, A. (2010), "On the meaning of work: a theoretical integration and review”, Research in Organizational Behavior, Vol. 30, pp. 91-127, doi: 10.1016/j.riob.2010.09.001.

Rupp, D.E. (2011), "An employee-centered model of organizational justice and social responsibility", Organizational Psychology Review, Vol. 1 No. 1, pp. 72-94, doi: 10.1177\%2F2041386610376255.

Rupp, D.E. and Mallory, D.B. (2015), "Corporate social responsibility: psychological, person-centric, and progressing”, Annual Review of Organizational Psychology and Organizational Behavior, Vol. 2 No. 1, pp. 211-236, doi: 10.1146/annurev-orgpsych-032414-111505.

Rupp, D.E., Shao, R., Thornton, M.A. and Skarlicki, D.P. (2013b), "Applicants' and employees' reactions to corporate social responsibility: the moderating effects of first-party justice perceptions and moral identity", Personnel Psychology, Vol. 66 No. 4, pp. 895-933, doi: 10.1111/ peps.12030.

Rupp, D.E., Shao, R., Skarlicki, D., Kim, T.Y. and Nadisic, T. (2013a), "Corporate social responsibility and employee engagement: the moderating role of self-determination and individualism", paper presented at the Academy of Management, 9-13 August, Orlando, FL. 
MRJIAM 18,4

\section{8}

Rynes, S.L., Colbert, A.E. and O’Boyle, E.H. (2018), "When the "best available evidence" doesn't win: how doubts about science and scientists threaten the future of evidence-based management", Journal of Management, Vol. 44 No. 8, pp. 2995-3010, doi: 10.1177/0149206318796934.

Stahl, G.K., Brewster, C.J., Collings, D.G. and Hajro, A. (2020), "Enhancing the role of human resource management in corporate sustainability and social responsibility: a multi-stakeholder, multidimensional approach to HRM", Human Resource Management Review, Vol. 30 No. 3, pp. 100708, doi: 10.1016/j.hrmr.2019.100708.

The Economist (2020), "How generous are America's rich?", available at: www.economist.com/graphicdetail/2020/05/06/how-generous-are-americas-rich

Waddock, S.A. and Graves, S.B. (1997), "The corporate social performance-financial performance link", Strategic Management Journal, Vol. 18 No. 4, pp. 303-319, doi: 10.1002/(SICI)1097-0266(199704) 18:43.0.CO;2-G.

We Are Intel (2020), "Intel heros: bringing masks, meals, and more to the front line", available at: https://blogs.intel.com/jobs/2020/04/intel-heros-2/.

Weick, K.E. (1995), Sensemaking in Organizations, Sage, Thousand Oaks, CA.

Weise, K. and Conger, K. (2020), "Gaps in Amazon's response as virus spreads to more than 50 warehouses", The New York Times, available at: www.nytimes.com/2020/04/05/technology/ coronavirus-amazon-workers.html

Williams, T.A., Bruber, D.A., Sutcliffe, K.M., Shepherd, D.A. and Zhao, E.Y. (2017), "Organizational response to adversity: fusing crisis management and resilience research streams", Academy of Management Annals, Vol. 11 No. 2, pp. 733-769, doi: 10.5465/annals.2015.0134.

\section{About the authors}

Herman Aguinis is Avram Tucker Distinguished Scholar, Professor and Chairperson of the Department of Management at The George Washington University School of Business. His research addresses the acquisition and deployment of talent in organizations and organizational research methods. He has published about 170 articles in refereed journals and 9 books, is Past President of the Iberoamerican Academy of Management and has been elected as the President of the Academy of Management. The 2019 and 2018 Web of Science Highly Cited Researchers Reports ranked him among the world's 100 most impactful researchers in Economics and Business. Herman Aguinis is the corresponding author and can be contacted at: haguinis@gwu.edu

Isabel Villamor is PhD Candidate in Management at The George Washington University School of Business. Her research focuses on leadership, star performers, virtual work, diversity and research methods and has been published in Journal of Management, Organizational Research Methods and elsewhere. She obtained Master of Business Administration from IESE Business School and degree in International Business from the University of Navarra. Before entering academia, she was Senior Consultant at Monitor Deloitte, where she worked for Global Fortune 100 companies in Europe and Latin America.

Kelly P. Gabriel is PhD student in Management at The George Washington University School of Business. Her research focuses on diversity, inclusion, equity, the work-life interface and research methods. She obtained Master of Science in Psychology and Bachelor's in Business Administration, both from Villanova University. Her research has been presented at the meetings of the Academy of Management and Society for Industrial and Organizational Psychology. Before entering in academia, she worked in community education for a non-profit and in finance for The Vanguard Group.

For instructions on how to order reprints of this article, please visit our website:

www.emeraldgrouppublishing.com/licensing/reprints.htm

Or contact us for further details: permissions@emeraldinsight.com 